\title{
Lesson Study To Improve Quality Of Learning
}

Luluk Indarinul Mufidah, Muh. Barid Nizarudin Wajdi

STAI Miftahul Ula Nganjuk

Baridnizar84@gmail.com

\begin{tabular}{|c||c||c|}
\hline Received: & Reviewed : & Published: \\
March 10, 2017 & May, 202017 & October, 30 2017 \\
\hline
\end{tabular}

\begin{abstract}
The school is a formal institution that helps especially parents in educating their children. Schools provide the knowledge, skills, and attitudes to their students in full accordance with what they need. Teachers are required to be able to master the curriculum, mastering the material, master the methods, and not least the teachers should also be able to manage the class in a way that learning takes an active, innovative and fun. Therefore, this paper will explore how a Lesson study engage an improve on their activity in teaching and quality of learning. This study will focus only on Lesson study method. Research findings show that With the Lesson Study, it will increase the quality of teaching and learning goals will be more easily achieved because there are a good cooperation and unity among teachers.
\end{abstract}

Keyword : Lesson study, Improve, Quality of learning

\section{A. INTRODUCTION}

The school is a formal institution that helps especially parents in educating their children. Schools provide the knowledge, skills, and attitudes to their students in full accordance with what they need. All these schools function will not be effective if the components of the school system did not work well, because of the weakness of one component will affect the other components, which in turn will also affect the way the system itself. one of the component parts of the school are the teachers. Teachers are required to be able to master the curriculum, mastering the material, master the methods, and not least the teachers should also be able to manage the class in a way that learning takes an active, innovative and fun. Teachers demanded to always improve the quality of learning by reviewing the processes and outcomes, so that really be a professional teacher who can deliver their students achieve success. ${ }^{1}$

${ }^{1}$ Ramsden, P. (2003). Learning to teach in higher education. Routledge. 


\section{B. DISCUSSION}

\section{Understanding Lesson Study}

Learning or learning is an activity that must be done and given by a teacher to the students. Because he is the key to success fatherly reach a bright future, preparing a generation of people with a high scientific insight. Which will eventually be useful for the nation, the state, and religion. ${ }^{2}$ Seeing the role is so vital, then apply an effective and efficient method of learning is a must, with the hope of teaching and learning process will run with fun and not boring. Lesson Study in Japanese is called Jugyokenkyu is a form of activity carried out by a teacher / group of teachers who work together with other people (lecturers, professors same subject / teachers of the same grade level, or teacher others), designing activities to improve the quality of students' learning of learning undertaken by one of the masters of the learning plan designed together with his / her own, and then observed by another teacher friend and after that they reflected together on the observations he has just done. ${ }^{3}$ Reflection is a discussion by observers and teacher educators to enhance the learning process where the focus the discussion on how students learn when students learn, when students begin to get tired of getting knowledge and when students are able to explain to his friend and when students are able to teach the entire class. ${ }^{4}$

Lesson study gives a real chance to teachers to watch the learning (teaching) and learning or the learning process of students (learning) in the classroom. Lesson study guide teachers to focus their discussions on the planning, execution, observation/observation, and reflection on classroom practice. By watching the actual teaching practices in the classroom, teachers can develop the same understanding or description of what constitutes effective teaching, which in turn can help students understand what they are learning. Other unique characteristics of lesson study are that the lesson study to keep the students has always been the heart rate of teacher professional development activities. Lesson study gives teachers the opportunity to closely examine the process of learning and student understanding by observing and discussing classroom practice. This opportunity also strengthens the role of

\footnotetext{
2 Wekke, I. S., \& Lubis, M. A. (2016). A Multicultural approach in Arabic language teaching: creating equality at Indonesian pesantren classroom life. Sosiohumanika, $1(2$

${ }^{3}$ Yoshida, M. (1999, April). Lesson study [Jugyokenkyu] in elementary school mathematics in Japan: A case study. In American Edu cational Res earch Association (1999 Annual Meeting), Montreal, Canada.

4 Astuti, P. (2017). UPAYA MENINGKATKAN PEMBELAJARAN TEMATIK MELALUI LESSON STUDY BAGI GURU KELAS I, II, DAN III SD NEGERI 2 GEDONGMULYO KECAMATAN LASEM KABUPATEN REMBANG PADA SEMESTER II TAHUN PELAJARAN 2014/2015. DIDAKTIKA PGRI, 2(2), 238-246.
} 
the teacher as a researcher in the classroom. Teachers make hypotheses (for example, if we teach a certain way, children will learn to be more active) and test it in the classroom with students. Then the teacher collects data when the observations of the students during learning and determine if that hypothesis is confirmed or not in the classroom.

Another hallmark of lesson study is that he is a teacher-led professional development. Through lesson study, teachers can be actively involved in the change process of learning and curriculum development ${ }^{5}$. In addition, collaboration can help reduce isolation among teachers and develop a common understanding of how to systematically and consistently improve the learning process and the learning process in the school as a whole. In addition, lesson study is a form of research that allows teachers take a central role as a researcher class of their own practice and become autonomous thinkers and researchers about learning (teaching) and learning or the learning process of students (learning) in classrooms throughout his life.

\section{History Lesson Study}

Terms lesson study itself was created by Makoto Yoshida. This practice has a long history and has significantly helped the improvement in learning(teaching) and learning/learning (learning) students in the class, as well as in curriculum development. ${ }^{6}$ Many primary school teachers and secondary school in Japan stated that lesson study is one of the important professional development approaches that has helped them grow as professionals throughout their carrier (Yoshida 1999) ${ }^{7}$. In Japan, teachers can improve the skill/proficiency in their teaching through lesson study, the learning of a lesson. Lesson study is one form of teacher development (in-service) that can be done to improve the professionalism of teachers. Lesson study conducted in the region by using the class teachers teaching in a real environment, so it will familiarize teachers collaboratively work well with subject teachers and with teachers outside of the field of study, even with the public and experts. Lesson Study is a collaboration between teachers in preparing lesson plans along with research, the implementation of classroom teaching is accompanied observation and reflection. Teachers with lesson study can freely improve performance and professionalism which can ultimately improve the quality of learning. Lesson Study is a process to develop

${ }^{5}$ Rodk, T. C., \& Wilson, C. (2005). Improving teaching through lesson study. Teacher Education Quarterly, 32(1), 77-92.

${ }^{6}$ Fernandez, C., \& Yoshida, M. (2012). Lesson study: A Japanese approach to improving mathem atics teaching and learning. Routledge.

7 Yoshida, M. (1999). Lesson study: An ethnographic investigation of school-based teacher development in Japan. Unpublished doctoral dissertation, University of Chicago. 
the professionalism of teachers in Japan with the probe / test their teaching practice in order to become more effective. ${ }^{8}$ Lesson Study was introduced in Indonesia through piloting activities undertaken in follow-up project IMSTEP-JICA at three universities, namely UPI, UNY, and UM. UM in itself study lesson in Malang formally introduced by JICA expert Eisoke Saito, Ph.D. in January 2004, followed the activities implementing lesson study in SMA Laboratorium State University of Malang (I Made Sulandra, 2006). Lesson Study is a new thing for most of most teachers. Lesson Study is adopted from Japan and is being piloted in some schools as a pilot project, including Bandung (UPI below), Yogyakarta (UNY below), and in Malang (UM below).

\section{Lesson Study Process}

In order to start the lesson study activities than in need of a change from the inside teachers that have an attitude as follows: 1). The spirit of introspection about what has been done so far to the learning process. Questions like whether I've done to educate well? Did I do the task as optimally as possible? A series of questions that must be answered truthfully, the answer will certainly encourage the process of finding ways to improve upon the deficiencies of the response. 2). The courage to open up to be able to receive advice from others to self-improvement. 3). The courage to admit mistakes yourself. 4). Courage recognizes and wears other people's good ideas. 5). Courage give honest feedback and respectful ${ }^{9}$.

Fifth those attitudes into requirements that must be understood and sharpened before we conduct Lesson Study. In addition to the basic attitude which must be prepared by the teacher, it is also very important the role of the components involved in the field of education, the principal, MGMPs, Office of Education, University and caregivers education on real commitment in supporting the activities of lesson study. ${ }^{10}$

Broadly speaking lesson study includes three (3) stages: planning activities (planning), implementation (action) learning and observation, and reflection (reflection), the details of the three stages as follows: ${ }^{11}$

${ }^{8}$ Lieberman, J. (2009). Reinventing teacher professional norms and identities: The role of lesson study and learning communities. Professional development in education, 35(1), 83-99.

${ }_{9}$ Joharmawan, R. (2006). Pengalaman Lesson Study di Malang. Makalah Pelatihan Lesson Study untuk Meningkatkan Kompetensi Guru Berprestasi dan Pengurus MGMP Bidang MIPA dan Bidang Study Lainnya Jenjang SMP/MTs dan SMA/MA Wilayah Indonesia Timur.

10 Setiawan, A., Alias, M. B., Abdullah, A. G., \& Aryanti, T. (Eds.). (2017). Regionalization and Harmonization in TVET: Proceedings of the 4th UPI International Conference on Technical and Vocational Education and Training (TVET 2016), November 15-16, 2016, Bandung, Indonesia. Routledge.

11 Nation, I. S. (2013). Learning Vocabulary in Another Language Google eBook. Cambridge University 
a. Planning Phase.

At this stage, identification of problems that exist in the class that will be used to the agenda of lesson study and alternative solutions. Identification of the problems and solutions related to the subject (the subject matter) that are relevant to the class and the subject matter, the characteristics of the students and the atmosphere of the class, method or approach to learning, media, props, and evaluation of the process and learning outcomes. Further discussion of the election of the subject matter, the selection of methods and media according to the characteristics of students and the type of evaluation to be used. At the time of the discussion will appear discordant opinions and suggestions from teachers and experts. At this stage experts and senior teachers can propose new things that need to be known and applied by the teacher in the learning process later. It is important also to be discussed in the preparation of observation sheets, especially the development of indicators during the learning process, both the views of teachers and students. The indicators are compiled based on the lesson plan was created and defined basic competencies that will be owned by the students after participating in the learning process. From the results of the identification of a problem and solving it, then prepared and packaged as a learning device comprising:

1). Unit Lesson (SP)

2). Directive teach teachers (teaching guide)

3). Worksheets students (LKS)

4). Media or props learning

5). Sheet process assessment and learning outcomes

6). Sheet observation. ${ }^{12}$

This learning device can be prepared by a teacher or several teachers who previously had been no agreement on aspects of learning that has been planned. The results of the preparation of the plan should be discussed with other teachers and experts in the group to be refined.

b. Implementation Phase and observations.

At this stage, the teacher implement lesson plans that were drawn up, while experts and other teachers make observations using observation sheet that has been prepared. Additionally do video recording (audio-visual) that clicking "close up" special events

\footnotetext{
Press.

12 Clay, M. M. (1993). An observation survey of early literacy achievement. Hein emann, 361 Hanover St., Portsmouth, NH 03801-3912.
} 
during the implementation of learning.

c. Reflection phase.

At this stage the teachers implement lesson plans are given the opportunity to express his impressions for implementing the learning, both to themselves and the students are facing. Furthermore, observer (other teachers and experts) present the results of data analysis observations, particularly regarding the activities of students during the learning takes place, along with playback of recorded video lessons. Finally, teachers who perform these implementations will provide feedback on the comments of the observer. It is important that in this reflection phase, is reconsidering the lesson plans, whether they were appropriate and can increase the activity of students' performance. If there is no conformity, what things are not appropriate, the learning method, the material in BLM, media or props, or other. consideration is then used to improve future lea rning plan. Robinson (2006) suggest that there are eight stages based on the number of activities required in the implementation of lesson study, namely: ${ }^{13}$

a. Selection of topic lesson study

b. Reviewing syllabus to clarify the learning objectives for that topic and are looking for ideas from the material in the textbooks. The following work in groups to develop lesson plans.

c. Any team that has developed a lesson plan presents or presenting learning plan, while other groups to provide feedback until finally gained a better lesson plan.

d. Teachers are appointed by the group uses these inputs to improve the learning plan.

e. The designated teacher learning plan presented in front of all the lesson study group members to get feedback.

f. The designated teacher in greater detail restores learning plan and send to all members of the group of teachers so that they know how the learning will be implemented in the classroom.

g. Teachers can learn again about the plans for these learning and consideration of various aspects of the learning experience they have, especially focused on things that are important such as: the things that will do the teachers, the students' understanding, the process of problem-solving by students and possibilities will occur in the implementation of learning.

13 Fernandez, M. L., \& Robinson, M. (2006). Prospective teachers' perspectives on microteaching lesson study. Education, 127(2), 203-216. 
h. The designated teacher learning in the classroom to implement the plan, while the other teacher with lecturers/experts to observe in accordance with their respective duties to provide feedback to the teacher. Meeting reflection to be done immediately after the implementation of learning activities, to gather feedback from teachers observer, and finally comments from professors or outside experts about the whole process, as well as suggestions for enhancement of learning, if they repeat in their respective classes or to a different topic.

Of the eight stages overlooked their efforts in drafting and improving learning plan repeatedly to obtain the best lesson plans.

\section{Benefits Lesson Study}

Increased competence of teacher is an ongoing effort, in harmony with the progress and development of science and technology. As well as other professions, such as the medical profession; doctors should have increased competence continuously track progress and developments in medical science. Likewise, a teacher, a teacher who never want to try to improve teacher competence will be "frozen". Lesson study selected and implemented for lesson study is an effective way to improve the quality of learning that teachers and student learning activities. This is because:

a. The development of lesson study is done and based on the "sharing" of professional knowledge that is based on the practice and teaching results undertaken by the teachers.

b. The fundamental emphasis on the implementation of a lesson study is that students have the quality of learning.

c. The competencies expected of students put into focus and the main focal point in the classroom.

d. Based on real experiences in the classroom, lesson study can become the foundation for the development of learning.

e. Lesson study will put the role of teachers as researchers study. ${ }^{14}$.

Increased competence of teachers is mandated by Law No. 14 The year 2005 on Teachers and Lecturers. Efforts to improve teaching is not only a one-off event but rather an ongoing activity, which is carried out in accordance with the concept of a professional Continuing Development(CPD).Lesson study is one activity that is very appropriate to be included in the activities Teacher Working Group (KKG) and Subject Teachers Council

${ }^{14}$ Lewis, C. C. (2002). Lesson study: A handbook of teacher-led instructional change. Research for Better Schools. 
(MGMPs). Because the lesson study, teachers will make the learning process collegially and jointly to improve their competence.

There are some other important things that can be gained through the lesson study:

First, teachers will be more open to the outside world. Classrooms are not locked themselves to not accept another teacher to see what teachers do it every working day in the learning process is implemented. The teacher, also need to see what colleagues in the learning process.

Second, teachers will learn from each other and work together in improving the quality of the learning process through increased understanding, not only on the material, but also the methods, media and teaching aids, but also the valuation technique used in the learning process. Thus, the focus of lesson study is the study of learning in order to find the best practices (best practices), based on the experiences observed in several phases of learning undertaken by teachers.

Third, with the best practice, teachers will be trained to be able to try to generate new innovations in learning, through proposals on improvement suggestions given by his colleague, also through creativity-creativity that later appeared in teaching practice.

Fourth, the final result is expected to be obtained through this lesson study is a learning process more effective and efficient, are thus expected to improve student learning outcomes (student achievement).

The advantages of the methods of lesson study as follows:

a. Can be applied in every field, from the arts, languages, mathematics, and sport until at each grade level.

b. Can be carried out between the teacher/educator with a cross-school, resulting in friendship in the sense of a process of cooperation, collaboration, between teacher/educator (cooperative and collaborative and collegial), which in turn can strengthen the unity and cohesion and improve the quality of teachers and participants learners together.

c. Lesson Study has a double value in terms for children, students, students, pupils, students, learners and can increase innovation and creativity of a teacher/tutor/cleric/lecturer. For the group "giver", they benefit teaching while student with fellow teachers, the collaborative concept useful stronger than his own, as well as acts of worship. For those who are "given", child, student, students, pupils, students, learners, will have good luck, enables high-quality learning outcomes. 
d. With the onset of interactions between educators, lesson study can open and increase the open nature, mutual love, and affection, mutual "Asah, Asih and Foster". Besides, it can also be a platform or vehicle for the realization that life is very limited, teachers do not feel the most intense and perfect, is not willing to accept criticism and suggestions. But the lesson study was at armed cooperation and collaboration among teachers who are willing to be given feedback, criticisms, and suggestions. Teachers were given advice not feel slighted/scorned, in case of mistake or deficiency. As for the teachers who give critiques and suggestions are also not feel as angel sanctimonious self-righteous and most know. Educators who give critiques and suggestions would also have to be good, ethical with akhlaqul karimah.

\section{CONCLUSION}

\section{Conclusion}

Lesson study is one method that is capable of improving the professionalism of a teacher as well as a method capable of improving cooperation among teachers. This method consists of three stages of the planning, implementation, and reflection. With the Lesson Study, it will increase the quality of teaching and learning goals will be more easily achieved because there are a good cooperation and unity among teachers.

\section{Suggestions}

a. For an optimal learning process results then all should be good learning component and support. One of them arranges the class with LS models.

b. Model Lesson Study can be used for all subjects and in collaboration with several teachers and including the general public and experts, for it can be used as an alternative model for teachers to create learning process quality

c. Teachers should be open to innovation - creative innovation so that knowledge and insights learning about growing.

d. Teachers should understand that cooperation among teachers is needed to increase the professionalism 


\section{REFERENCES}

Astuti, P. (2017). UPAYA MENINGKATKAN PEMBELAJARAN TEMATIK MELALUI LESSON STUDY BAGI GURU KELAS I, II, DAN III SD NEGERI 2 GEDONGMULYO KECAMATAN LASEM KABUPATEN REMBANG PADA SEMESTER II TAHUN PELAJARAN 2014/2015. DIDAKTIKA PGRI,.

Clay, M. M. (1993). An observation survey of early literacy achievement. Heinemann, 361 Hanover St., Portsmouth.

Fernandez, C., \& Yoshida, M. (2012). Lesson study: A Japanese approach to improving mathematics teaching and learning. Routledge.

Fernandez, M. L., \& Robinson, M. (2006). Prospective teachers' perspectives on microteaching lesson study. Education, 127(2).

Joharmawan, R. (2006). Pengalaman Lesson Study di Malang. Makalah Pelatihan Lesson Study untuk Meningkatkan Kompetensi Guru Berprestasi dan Pengurus MGMP Bidang MIP A dan Bidang Study Lainnya Jenjang SMP/MTs dan SMA/MA Wilayah Indonesia Timur.

Lieberman, J. (2009). Reinventing teacher professional norms and identities: The role of lesson study and learning communities. Professional development in education, 35(1).

Lewis, C. C. (2002). Lesson study: A handbook of teacher-led instructional change. Research for Better Schools.

Nation, I. S. (2013). Learning Vocabulary in Another Language Google eBook. Cambridge University Press.

Prawiro, Bambang.(1991).Strategi Belajar Mengajar. Surakarta:UNS press.

W. Gulo.(2002). Strategi Belajar Mengajar. Jakarta:Grasindo.

Tim Lesson Study . (2006). Upaya Meningkatnya keprofesionalan Guru melalui Lesson Study. Bandung:FPMIPA UPI.

Ramsden, P. (2003). Leaming to teach in higher education. Routledge.

Rock, T. C., \& Wilson, C. (2005). Improving teaching through lesson study. Teacher Education Quarterly, 32(1).

Setiawan, A., Alias, M. B., Abdullah, A. G., \& Aryanti, T. (Eds.). (2017). Regionalization and Harmonization in TVET: Proceedings of the 4th UPI International Conference on Technical and Vocational Education and Training (TVET 2016), November 15-16, 2016, Bandung, Indonesia. Routledge.

Yoshida, M. (1999, April). Lesson study [Jugyokenkyu] in elementary school mathematics in Japan: A case study. In American Educational Research Association (1999 Annual Meeting), Montreal, 
Canada.

Yoshida, M. (1999). Lesson study: An ethnographic investigation of school-based teacher development in Japan. Unpublished doctoral dissertation, University of Chicago.

Wekke, I. S., \& Lubis, M. A. (2016). A Multicultural approach in Arabic language teaching: creating equality at Indonesian pesantren classroom life. Sosiohumanika, 1(2 